\title{
Meta
}

Journal des traducteurs

Translators' Journal

\section{Saint Dahl, Henry (1995) : Dahl's Law Dictionary/Dictionnaire Juridique Dahl (Fench-English, English-French), Buffalo, New York/Paris, William S. Hein \& Co. Inc./Dalloz, 851 p.}

\section{Wallace Schwab}

Volume 41, numéro 3, septembre 1996

URI : https://id.erudit.org/iderudit/004067ar

DOI : https://doi.org/10.7202/004067ar

Aller au sommaire du numéro

Éditeur(s)

Les Presses de l'Université de Montréal

ISSN

0026-0452 (imprimé)

1492-1421 (numérique)

Découvrir la revue

Citer ce compte rendu

Schwab, W. (1996). Compte rendu de [Saint Dahl, Henry (1995) : Dahl's Law Dictionary/Dictionnaire Juridique Dahl (Fench-English, English-French), Buffalo, New York/Paris, William S. Hein \& Co. Inc./Dalloz, 851 p.] Meta, 41(3), 475-478. https://doi.org/10.7202/004067ar d'utilisation que vous pouvez consulter en ligne. 
- SAINT DAHL, Henry (1995) : Dahl's Law Dictionary/Dictionnaire Juridique Dahl (French-English, English-French), Buffalo, New York/Paris, William S. Hein \& Co. Inc./Dalloz, 851 p.

In the highly eclectic business of commercial translation where getting a message from point $\mathrm{A}$ to point $\mathrm{B}$ must be accomplished with minimum alterations to content and style, practising translators know they must pay particular attention to understanding source language conceptual content plus social/stylistic spin, use the most efficient 
transfer techniques and devices to do the job, then carefully review the reconstituted target language message to ensure that it renders the original while integrating everything that target readers expect to find in texts of such kind. In a pluralistic operation such as this, success can only be relative and any explicit laboratory cases illustrating this complex process are always welcome. The constraints of legal translation and Dahl's Dictionary provide an interesting test-tube environment for demonstrating how semantic clusters of information from a message in one language find their way, may lose bits and pieces, or even get lost when being moved to another language.

As its bibliographical data suggest, Dahl's Law Dictionary is a one volume two-part French-English, English-French reference manual composed of French and American legal material in which it attempts to present its readership with ready solutions and explanations to a host of terminological phenomena. As seen from a Québec perspective, the act of looking over French and American shoulders and then comparing observations with our own homegrown (civil law/common law) versions of the same legal material, is a strenuous exercise in comparative law, linguistics, stylistics and much more. Bilateral comparisons are excellent for illustrating objectivity, but trilateral analyses raise the stakes of understanding to an even higher level: relativity.

As we already know, all legal systems are conceptual networks that derive their substance from social settings and they are expressed in whatever the languages of such societies may be. When juxtaposing two or more of these systems, the ensuing observation immediately becomes apparent: Each system has its own unique distribution of its conceptual elements and from one system to another, there may be componential parity, overlaps or empty sets. In Dahl's Law Dictionary, examples of all these abound in every direction.

PARITY

Cases of parity are often the easiest ones to deal with, but sometimes the most treacherous. Take Obligations, for instance, on page 313 et seq. The entries and their explanations read much like similar material extracted from Québec treatises on the subject by Baudouin, Pineau or Tancelin, which leads us to note the encyclopedic value of parts of Dahl's work. Yet this is only unilingual parity expressed in French illustrating institutions similar to Québec ones. So, the whole problem of expressing obligations in English raises the sticky question of what "legal lingo" is adaptable for describing such realities, certainly not common law terminology yet Québec and Louisiana have for years used their own solutions. The Dahl dictionary offers its own acceptable go-between-neither common law nor totally acclimatized English-whose only value to Québec readers is to be an interesting source of inspiration.

Another concept, the Porte-fort or guarantor on page 338 provides another example of conceptual similarity within civil law countries, but with the same aforementioned caveat.

Both of the preceding examples go strong on explanations, but are weak in setting forth examples of lexical equivalents in both languages and provide no insights into co-occurrents. This observation stands true for most of the entire dictionary and constitutes a primary weakness for translators.

\section{OVERLAPS}

Overlapping sets are by far a common occurrence in comparative law situations. Source and target language equivalents are often deceivingly close, but not quite the same, so some adaptation or modulation is required to get from language $\mathrm{A}$ to language $\mathrm{B}$.

The entry Leases, uniform commercial code on page 699 provides food for thought because the article is a misnomer. Instead of delving into commercial leasing 
practices (which I expected), Dahl immediately raises the specific case of third-party leasing, but doesn't call this financial creature by its name in English, so this provides no help for information retrieval. Now the American origin of third-party leasing means that both the French and Québec legal systems have at some point in time each copied from the original and in this case, they both agree on the same strange translation: crédit-bail. A weird rendering to say the least because how or why was crédit chosen by legislators in both countries?

Past the name, all similarities end. The underlying legal structures of leasing techniques in French law and in Québec law each go their own way, both obeying the imperatives of their own systems. This means that all supporting vocabulary will be derived from fundamental laws, which in Québec is C.C. art. 1842 to 1850 . So once again, the use of this dictionary in Québec is limited to being a source of comparison.

The same principle applies to Filiale: subsidy on page 197 because each national legislation will refer to its own laws on commercial corporations along with the vocabulary it uses to describe them. Naturally, the dictionary assumes that the reader knows all this.

An interesting set of explanations may be found under two concepts that are invoked when courts hand out orders: the saisie-arrêt in French law and the injunction in American law.

The concept of Saisie-arrêt on page 395 rings familiar to both Québec and French jurists; furthermore, any bi-continental meeting of the minds on this subject between French speaking jurists would probably take place in an atmosphere of congenial camaraderie and mutual understanding of technical details. Yet if pushed to write on the subject, French jurists would base their writings on the New French Code of Civil Procedure and their Québec counterparts would head straight for Québec C.P.C., art. 625 to 659.10 . Neither would spend much time in a dictionary.

This tacit admission that any legal dictionary is incomplete per se strikes an informed reader who glosses over Dahl's rendering of an injunction. As one may recall, an injunction is a prohibitive writ arising from the chancery court of equity, hence a creature spawned by a very special law court that behaves in its own peculiar manner. Despite this "red-flag" background, on page 233 Dahl gives an unexplained: Injonction: injunction, order on the French side and a slightly better Injunction: injonction, défense, ordre, ordre de ne pas faire, ordonnance de référé on the English side. One could say that this is tantamount to giving an uninformed individual a firecracker marked "light here" with no warning as to the consequences.

\section{EMPTY SETS}

Empty sets provide translators with the worst headaches and the greatest challenges for innovative expression. On page 96, Dahl succinctly explains the Conseil de prud'hommes or labor court, but only exposes the tip of the iceberg. The world of labor law is a galaxy unto itself and the words describing it are charged with variable meanings from one jurisdiction to another. For argument sake-or a good after-dinner exercise- the reader may consider researching in Québec law: congédiement, licenciement, mise à pied and suspension using as documentation: the Labour Standards Act, R.S.Q., c. N-1.1, the Occupational Health and Safety Act, R.S.Q., c. S-2.1, the Industrial Accidents Act, R.S.Q., c. A-3.001 and the Labour Code (R.S.Q., c. C-27. Afterwards, compare with French law and how these words may be used over there. Then to complete the triangle, gloss over workman's compensations acts as drafted in various American states. Note that in Dahl's Law Dictionary, most of his examples regarding labor law are extracted from the Laws of Puerto Rico Annotated (L.P.R.A.), which I would suspect are influenced both 
by U.S. statutory practices and South American codification techniques. Why Puerto Rico?

A dictionary such as Dahl's can offer useful insights into otherwise unknown realities as is the case with Groupement d'intérêt économique on page 215. In North America, there is no readily repeatable legislative procedure for creating an economic interest group; in Québec such an entity could be realized via a private bill.

\section{BACK TO QUÉBEC}

Now what does all this mean for the Canada-based translator who desperately seeks a solution for translating à toutes fins que de droit (for all legal (intents and) purposes), bon père de famille (progressively replaced in Québec by personne raisonnable: prudent administrator), société en participation: silent partnership (USA) and "undeclared partnership (Qc) and many other similar terms? One piece of simply complicated advice is BE CAREFUL! Know your laws, your languages and where the translated material will be used, then consult the dictionary for fun.

\section{LEXICAL PRESENTATION}

Dahl's Law Dictionary is a model of oblivion regarding standard dictionary drafting practices. In all, it is a linear compilation of words, expressions and mini-phrases set off in bold characters followed by a translation or an explanation. An occasional reference is given to words that may appear as either nouns or verbs. There are also curious haphazard uses of capital letters, punctuation and grammatical categories in strange places as in Bid on page 519:

Bid (n/v). Offre, enchère, mise (n). Contre-offre. Devis, soumission. Tentative Offrir, miser, inviter, prier. Commander, ordonner, faire une offre, enchérir ( $v)$.

There are also peculiar choices of lexical entries such as Big on page 519:

Big. Gros, grand, énorme, immense, considérable.

Very legal, indubitably! But then even a toothpick, if used in the commission of a heinous crime, acquires momentary legal fame and value... Eh wot!

Lastly, the reader will find a certain number of abbreviations explained that are current in France and the United States, which could be a life-saver during a late-night sprint to finish a text for the next morning-when all libraries are closed and your Internet server refuses you access, natch!

\section{THE LAST STRAW}

Dahl's Law Dictionary is obviously not for general consumption in Canada or anywhere else outside the France-USA connection. Nonetheless for specialists and comparatists, it does exercise an attraction owing to some of the source material used in the production of the manual and despite the impressionistic use of stylistic usages.

WALLACE SCHWAB Sainte-Foy, Québec, Canada 